\title{
Ong'ong'a: Edutainment through Reality TV Shows in China and its Export
}

\author{
Oloo Daniel Ong'ong'a1, \\ ${ }^{1}$ Institute of Communication Studies, Communication University of China, Beijing,10024, China
}

\begin{tabular}{llll}
\hline Received: 25. 11.2021 & • Accepted: 12.12.2021 & Published: 19.12.2021 \\
\hline
\end{tabular}

\begin{abstract}
In recent years, the Chinese media has grown vastly with the country's interest in the investment in the developing countries. As the relationship with these countries become, so as the influence of Chinese culture towards the nations through the ever-growing Chinese media. Since the implementation of significant projects in Africa, Caribbean and Asia countries by Chinese government, the Chinese media have been characterized in localizing their TV contents to compete with the host countries and stretching their sense of soft power to these nations. Although they have faced significant challenges in terms of cultural difference, and technological development, the Chinese reality TV shows have continued to be part of the regular host countries' TV program diet while facing fierce standpoint from the initial global dominant media in these markets. This paper analyses these trends in focus on the Chinese reality TV shows that have hit the host countries' market as well as the motivation of their evolution. The article traces the extent of these strategies to be leveraged by states to balance their local production and foster cordial relation with China in a context of edutainment. It is imperative to analyze the development of this crucial phenomenon in the ontological perspective of the internationalization and marketization of products. The article addresses these issues by drawing attention from different players in this conspicuous field.
\end{abstract}

Keywords: edutainment, glocalization, internationalization, marketization, reality TV shows, China

\section{INTRODUCTION}

The trend of glocalization of reality TV shows is becoming increasingly prominent recently in the context of edutainment. Specifically, in China, different scholars have immersed themselves in this field and documented various studies on the glocalization and alteration of China reality TV programs by establishing the relationship between Chinese and foreign reality TV programs. Zhang and Guo, (2012) argue that the Reality TV shows in China are imported goods which is the continuous introduction and research of the country, that has finally taken root and gradually the country has begun to form its brand. The need to recognize the contemporary shortcomings of the reality shows in China and the outside market is vital for the ever-competitive internationalization of the television programs. Due to the characteristics of the novel form, China's reality TV program in recent years has shown a blowout type of development (Richeri, 2016). The primary field which has been of interest include categories of; field survival; entertainment draft; marriage and love, education and workplace. The performance environment for these reality TV shows has also transformed from the initial field to the indoor, studio and concert-style of the giant stage. The audience is directly addicted to the colorful style of these TV shows (Takahashi et al., 2015; Zhang \& Guo, 2012), making them accessible in the technological age in China. 
The potential of Reality TV programming became apparent in the U.S. in 1948. Since its inception, the TV broadcast industry throughout the world has been flooded with these unscripted dramas. In China, this genre of TV programming has been successfully thriving since launching the 'Great Challenge for Survival (Shengcun da Tiaozhan) program in the year 2000 (Zhang \& Guo, 2012). To date, there are over 100 realities TV shows that can be found on the 3,000 plus TV stations across the thirty-three provinces municipalities and special regions across China. The main reasons attributed to this exponential growth in reality television are the constantly changing media landscape, audience demographics and viewing patterns coupled with the massive internet penetration in China as well as access to education content by young people (Richeri, 2016).

The vast Reality TV shows in China face a lot of challenges when they are exported for consumption. Thus, it is essential to take note that the need to expose international participation is vital for the glocalization of these products. Such may include avenues like a strategic alliance with partners in the market internationally. The development of this relationship creates a network for reality TV creation in local language that may meet the needs of the consumers. The aspect of ethnicity in the Chinese group, have a basis of developing business networks of social reality through shared values. These values could be learned through people to people exchange programs during reality shows production. The tendency of the rapid growth of the electronic market is a contemporary requirement for the Glocalization (Richeri, 2016; Zhengrong et al., 2013). Similarity versus the proximity of overseas market psychic distance influence the selection of the foreign markets, these markets play a crucial role in determining reality TV that are important in the education before they are exported.

\subsection{Screening Reality TV in China}

The structure of the Chinese media system induces the opportunity to explore the entirety of its functions. The four-tier broadcasting system is based on the hierarchical government structure - of national, provincial, municipal and county - each division having its wide-range of channels (Jiang, 2013). This oversaturated market has media houses in constant competition because of the lack of public funding. Thus, each is trying to remain a viable option for viewers, to maintain or increase ratings and bottom-line goals. It was realized that the TV education entertainment genre garnered large receptions from audiences. Such as 'peoples real show' or 'Zhenren Xiu' instigated a shift in the audience attention and thus these programs have claimed the primetime slots from the traditional fictional drama series (Zhu, 2008). To maintain market shares, many TV networks have either joined arms with independent production companies to reduce internal production costs or have bought franchise rights to top-rated international reality TV show models to guarantee success.

The leading players in the reality TV industry in China is broadcasting networks. The networks belong to either the state-owned tier like CCTV and the provincial level like that of; Wasu Media Holding Co. Ltd.; Hunan TV \& Broadcast Intermediary Co.; Ltd., Beijing Gehua CATV Network Co. Ltd.; Shaanxi Broadcasting \& TV Network Intermed; Shanghai Media Group (SMG); Zhejiang TV and Anhui TV (Zhang \& Guo, 2012).

For instance, at the Provincial satellite television tier, Shanghai's Dragon TV bought franchise rights for China's Got Talent for one million Yuan from international owners Fremantle Media. Moreover, it self-produced another show Roommate Wanted which was presented on the late-evening slot. Over the years, Hunan Broadcasting System has produced several shows including the Perfect Vacation, Super Girl, Super Boy, Chinese Restaurants and I am a Singer. Satellite TV channel Zhejiang TV produced Chase Me. Sichuan Satellite TV (SSTV), also on the provincial government level bought production rights from America's Next Top Model to provide China's Next Top Model (Zhang \& 
Guo, 2012). After SSTV failed to renew the contract rights, Chongqing TV another provincial level station renamed the series I Supermodel and aired it for three seasons. Some provincial networks like Jiangsu Broadcasting Corporation have been known to produce and broadcast their shows, for instance, the dating game If You are the One.

Private production organizations have gotten in on the game, and have been producing shows that are aired on television stations throughout China. Star China Media produces I Sing which is broadcasted on Zhejiang TV; The Voice of the Silk Road is produced by Talpa and is aired on Xinjiang Television a county TV channel. In Hong Kong, for instance, a company such as R by R limited presents a series of a weekly travel show with a set in Japan (Takahashi et al., 2015).

Tencent, Baidu and Weibo as tech giants in China have gotten in on the reality TV concept and have introduced these shows for their live-streaming video market. In some cases, they are becoming independent producers. For example, Baidu's video streaming platform iQiyi produces The Rap of China competition show. Street Dance of China is another popular online reality show on the Youku video site (Armstrong, 2019; Cheng, 2019). The above examples show how vast Chinese reality TV shows have emerged recently and how they have managed to ensure they continue to produce edutainment contents.

\section{METHOD}

In order to trace the edutainment TV reality shows in China media space, the study utilized a qualitative approach. The secondary data were generated from different relevant academic journals articles, books and publications. The justification of this methodology is because it offers a wider spectrum of materials to be reviewed and analyzed. A textual and content analysis was performed to ensure that data generated were in line with the scope of the study. For instance, information that needed to be translated from Chinese to English in the table 1 below a qualified translator was engaged so that the meanings of the texts could be achieved.

\section{FINDINGS AND DISCUSSION}

\subsection{Country Market Potential}

The investment of Chinese into Africa and other countries of their interest has created a possibility for the readily market not only for goods and services but also for the TV industry's products like TV reality shows. Countries such as Tanzania, have managed to learn Chinese culture with the influence of local Chinese drama that is aired in the national television station. Therefore, these have created the potential of Chinese to produce more contents of reality TV for these consumers. On the other hand, the integration of the African characters as well as the use of Swahili language, has allowed for swift inclusion of such commodity into the market in Kiswahili spaking countries such as Kenya, Uganda, DRC and Rwanda among others.

Even though the issue of marketization has brought about a series of problems, the authorities in China have also taken relevant measures in this regard-the promulgation of the "limited entertainment order". Zhang and Guo, (2012) point out that the rise of the restriction order effectively reduces the vulgarity of the content of the reality TV program and curbs the social phenomenon of excessive entertainment, which is very necessary. However, there is a need for versatile efforts to create a genuinely harmonious television market. It is evident that reality TV in the process of localization has seemed like blind follow and vulgarity (Jiang, 2013). Therefore, one cannot deny that reality TV shows have largely enriched the entertainment industry of China but also to the rest 
of the world, especially in countries, which it has majorly invested, in education and Confucius institutes.

\subsection{Context Specification of Reality TV Shows}

The context of the production of the different reality TV shows plays a significant role in its consumption in both the global and local markets. It is vital to keenly keep an eye on their reality TV production industry, and trying to support it with state aid and, in some periods, to protect it. The Chinese model of reality TV has been pegged in the continuum of expression of the culture and tradition of the country. In this aspect, going global and local makes them avoid political and economic agendas of the countries that are oriented towards cultural sensitivity (Zhengrong et al., 2013). Various supporting bodies within different countries have made it possible for the insurance of making reality TV shows a crucial element in the integration of culture in the broader sphere of the nationals. Chinese cinema's industries have been strengthening to make them more competitive and market-driven (Richeri, 2016). The increase in reality TV shows strives the inadequacies in the creativity, which is accompanied by a lack of motivation which challenges the program popularity (Cheng, 2019). These shows are drawn from popular foreign ones or derive from the domesticated ones by producers. Even though the producers might have a proficiency in the production of highquality pieces, there rich cultural content is therefore compromised. Reality shows in China have been documented to be the most popular in the country presently. This shift is propagated by the increase of technological development with the immense penetration and access of the affordable internet through cheap Chinese mobile smartphones flooding the market.

\subsection{Quality fragmentation}

Many reality TV shows in China are the alteration of external reality shows, but Chinese producers localize these shows to suite the Chinese cultural and national identity market (Richeri, 2016). In 2013, Hunan Satellite TV launched an extensive reality TV parent-Child program "Daddy Go where" which quickly became famous all over the country. The copyright and style of this program are the full introductions of South Korea's MBC television program "Daddy! Where are we going?" Again, in October 2014, a particularly hot TV show on Zhejiang TV, 'Running the brothers', was the "Running Man" of Korea's SBS TV station. Y.Z. Xu and F. Xu, in their article on 'Typology of TV Programs', said these two realities TV shows have been hugely successful, and this means that South Korea still has something they need to learn and draw on when it comes to TV shows (Richeri, 2016). The core of the Korean reality TV star system is to establish the star's unique personality positioning, and the focus of reality TV is to show the participants ' charisma. In this regard, South Korea's star system and reality show have a perfect combination, thus creating Korean characteristics of the star reality show. Based on this style, China's introduction of "Daddy Go where" and "Run Bar" have adopted this star system, in the program to obtain the viewing craze at the same time, but also popular to participate in the production of real people, so that their image is fuller and more beloved (Richeri, 2016; Takahashi et al., 2015; Yiming, 2020).

The quality of the production has rocketed the higher consumption of Chinese reality TV shows in Africa platforms. In terms of content and messages that are crafted in the needs of the consumers. Different from the western reality TV shows where they are majorly focused on the idols, the changing trends of China reality TV shows have created a different narrative in fostering the element of humanity and humour but solving social problems in general (Richeri, 2016; Takahashi et al., 2015; Zhang \& Guo, 2012). Although the multiple languages that are spoken in African countries 
prove to be a challenge, China has invested in these countries structurally by the provision of technology-enabled devices for the access of the reality TV shows. The dubbing of the contents of these shows has made it possible for their seamlessly integrated into these markets. The highly censored characterizes of these reality TV shows avoids the impediment of political discursiveness hence ensuring the non-partisan nature of the influence in any kind of political ideologies of the different countries (Jiang, 2013; Zhang \& Guo, 2012).

\subsection{Policies on Glocalization of RTS}

Audience's exposure to other countries reality TV Shows has pushed local reality TV Shows producers to be more creative, following China's State Administration of Radio, Film and Television (SARFT) vision (Cheng, 2019). SARFT declares a Directive in June 2016, which covers the reality TV production, which is adapting the foreign shows (Cheng, 2019). The directive limits similar or join-cooperation production with international producers to protect local production and pushes the local producers to be more creative (Zhang \& Guo, 2012). On the downside, this has limited the opportunity to learn from different reality TV shows for then localizing and globalizing the programs. However, following the national agenda to promote national heritage, the creativity hits local producer and gain popularity for reality TV shows that it is rich in Chinese culture (Armstrong, 2019). One of the successful TV Show that gains popularity upon the premiere is The Story of Minglan. This show premiered on Hunan TV and earned 400 million views over three days of its release (Yiming, 2020).

Other policies supporting the Glocalization of Chinese reality shows are the signatory of WTOTRIPS (Jiang, 2013). These agreements positively help the local reality TV shows produced to then have their copyright upon the release to the international audience. Each of the content provided is also reviewed and approved by the Format Recognition and Protection Association (FRAPA). FRAPA's supra note 34, at 10 explains, "Copyright law protects categories of creative works, such as literary, artistic, musical and dramatic works (Jianguo \& Xin, 2012). Copyright will not protect a concept or an idea such as e.g., an outline or a high-level plot."

After the affirmation of this law and also China's signatory member of several copyright agreement, the production of the local show has been escalating in creativity (Cheng, 2019) as well as popularity. With reality TV Shows that are rich in nationality and Chinese Culture -also contemporary culture-, the international market could have more perspective about China and enjoy the China-taste entertainment. Development of technology also helps to promote this TV shows by showing them on digital platforms. Chinese TV series is the homogenous population in digital platforms. It is not in doubt that reality TV shows would expand their broadcast to international platforms to offer the global market a high-quality Chinese content (Armstrong, 2019; Sender \& Garrahan, 2016; Zhang \& Guo, 2012).

\subsection{The Progression of RTS}

The findings of this study revealed that most of the international reality TV shows have their copy in the local Chinese television. The strategy adopted here by the Chinese is to make sure that they compete effectively with the global markets. Most of the viewership in China are in their youthful stage and hence seek to acquaint themselves with the programme around the world. The local TV stations in China therefore, have taken these opportunities to cast the same programmes but in their local language. Furthermore, most of the reality TV shows originated from the European markets, 
while a few of them from Korea. It is interesting to note that none of these reality TV shows have been crafted for African market yet.

Table 1. Overview of the reality TV progression.

\begin{tabular}{|c|c|c|c|c|}
\hline $\begin{array}{l}\text { Original } \\
\text { Programme }\end{array}$ & Origin & Chinese Version & Broadcaster & License \\
\hline $\begin{array}{l}\text { Take Me Out/ } \\
\text { Taken Out }\end{array}$ & Uk/Australia & $\begin{array}{l}\text { If you are the One } \\
\text { Féi chéng wù răo }\end{array}$ & Jiangsu Satellite & No \\
\hline The Biggest Loser & NBC/US & $\begin{array}{l}\text { The biggest loser } \\
\text { C hào jí jiănféi wăng }\end{array}$ & Cetv2 & Yes \\
\hline I Am A Singer & Korea/MBC & $\begin{array}{l}\text { I am a singer } \\
\text { Wó shìgè shòu }\end{array}$ & Hunan Satellite & Yes \\
\hline Pop IDOL & UK/Fremantle media & $\begin{array}{l}\text { Supergirls } \\
\text { Chào jí nùshēng }\end{array}$ & Hunan Satellite & No \\
\hline $\begin{array}{l}\text { Where Are We } \\
\text { Going, Dad? }\end{array}$ & Korea/MBC & $\begin{array}{l}\text { Where are we going, dad? } \\
\text { Bàba yào qù nălĭ? }\end{array}$ & $\begin{array}{l}\text { Hunan Satellite } \\
\text { TV }\end{array}$ & Yes \\
\hline Pop Idol & UK/Fremantle media & $\begin{array}{l}\text { Chinese idol } \\
\text { Zhóngguǒ mèng zhī shēng }\end{array}$ & Dragon TV & No \\
\hline Granddads & Korea/CJ E\&M & $\begin{array}{l}\text { Granddads } \\
\text { Hu a yáng yéyé }\end{array}$ & Dragon TV & Yes \\
\hline $\begin{array}{ll}\text { Britain's } \quad \text { Got } \\
\text { Talent }\end{array}$ & UK/SYCO TV & $\begin{array}{l}\text { China's got Talent } \\
\text { Zhóngguǒ mèng zhī shēng }\end{array}$ & Dragon TV & Yes \\
\hline Shall We Dance & $\begin{array}{l}\text { Philippines/Australia. - } \\
\text { ABC }\end{array}$ & $\begin{array}{l}\text { Let's shake it } \\
\text { Wǔlin dàhuì }\end{array}$ & Dragon TV & No \\
\hline The Voice & Netherlands/Talpa & $\begin{array}{l}\text { The song of China- } \\
\text { zhonnguo hao shenyin }\end{array}$ & $\begin{array}{l}\text { Hunan Satellite } \\
\text { TV }\end{array}$ & Yes \\
\hline $\begin{array}{l}\text { So You Think You } \\
\text { Can Dance }\end{array}$ & US/FOX & $\begin{array}{l}\text { Super diva } \\
\text { Wú lǐng zhēngbà }\end{array}$ & Dragon TV & Yes \\
\hline The Voice & Netherlands/Talpa & $\begin{array}{l}\text { The song of China } \\
\text { Zhōngguó dá rén xiù }\end{array}$ & $\begin{array}{l}\text { Zhejiang } \\
\text { Satellite TV }\end{array}$ & Yes \\
\hline The Apprentice & The U.S. & $\begin{array}{l}\text { Win in China } \\
\text { Yíng zài zhōngguó }\end{array}$ & CcTV 2 & No \\
\hline The X Factor & UK/SYCO TV & $\begin{array}{l}\text { The x-factor China } \\
\text { Zhōngguó zuì qiáng yīn }\end{array}$ & Hunan Satellite & Yes \\
\hline Ugly Betty & Columbia & $\begin{array}{l}\text { Ugly Betty } \\
\text { Chóu nü bèidì }\end{array}$ & Hunan Satellite & Yes \\
\hline
\end{tabular}

\section{CONCLUSION}

This article explores the extent of the Chinese reality TV shows on its inception to what it could be termed as the transformation to the outside world with the marketization characteristics. It is worth noting that the significant trend of the development of the reality shows by the Chinese is skewed to the adaptation of the western and European paradigm of infotainment. This can be witnessed by western-like drama and TV series being broadcasted in various foreign and local TV channels. With the growing interest of China to the developing nations, including Africa in particular, it is interesting to document the integration of Chinese language in the production of reality shows to suit their 
international allies. Although this is seen as a strategy of seamlessly fitting into these markets, the argumentation could be based on the significant influence of their soft power to gain an advantage over these nations. Therefore, this paper postulates the exploration of the perception of foreign TV consumers towards Chinese reality TV shows.

\section{REFERENCES}

[1] Armstrong, J. K. (2019). BBC - Culture-What this historical T.V. show reveals about China today. http://www.bbc.com/culture/story/20190805-what-this-historical-tv-show-reveals-about-China-today

[2] Cheng, F. (2019). Behind The Low Originality Of Chinese, Reality TV Shows Copyright Protection And Government Regulation For Localization. 16(4), 21.

[3] Jiang, F. (2013). On the three waves of China's communication studies: A commemoration of the 30th anniversary of Schramm's visit to China \& China's communication studies in post-Schramm times. Studies in Communication Sciences, 13(2), 107-116. https://doi.org/10.1016/j.scoms.2013.11.005

[4] Jianguo, X., \& Xin, T. (2012). Cost And Fee Allocation In Civil Procedure: China National Report.

[5] Richeri, G. (2016). Global film market, regional problems. Global Media and China, 1(4), 312-330. https://doi.org/10.1177/2059436416681576

[6] Sender, H., \& Garrahan, M. (2016, June 8). Chinese investors flood into Hollywood. https://www.ft.com/content/2cb93908-2c65-11e6-bf8d-26294ad519fc

[7] Takahashi, M., Clippingdale, S., Naemura, M., \& Shibata, M. (2015). Estimation of viewers' ratings of T.V. programs based on behaviours in home environments. Multimedia Tools and Applications, 74(19), 86698684. https://doi.org/10.1007/s11042-014-2352-0

[8] Yiming, W. (2020). Top 5 Chinese dramas that became popular overseas in 2019-China.org.cn. http://www.China.org.cn/arts/2020-01/17/content 75623198_3.htm

[9] Zhang, X., \& Guo, Z. (2012). Hegemony and counter-hegemony: The politics of dialects in T.V. programs in China. Chinese Journal of Communication, 5(3), 300-315. https://doi.org/10.1080/17544750.2012.701421

[10] Zhengrong, H., Deqiang, J., \& Lei, Z. (2015). Building The Nation-State. 27.

[11] Zhengrong, H., Lei, Z., \& Deqiang, J. (2013). Globalization, social reform and the shifting paradigms of communication studies in China. Media, Culture \& Society, 35(1), 147-155. https://doi.org/10.1177/0163443712464569 